\title{
NUTRITIONAL VALUE OF NEW UNCOOKED SMOKED PORK PRODUCT
}

\section{ПИШЕВАЯ ЩЕННОСТЬ ИННОВАЦИОННОГО СЫРОКОПЧЕНОГО ПРОДУКТА ИЗ СВИНИНЫ}

\author{
Zabalueva Yu.Yu., Bazhenova B.A., Nazimova K.S. \\ East-Siberian State University of Technology and Management, Ulan-Ude, Russia
}

Ключевые слова: мясной продукт, пищевая иенность, стартовые культурь, плоды шиповника

\section{Аннотация}

В статье представлены результаты исследования пищевой ценности сырокопченого изделия из свинины с использованием сложного рассола. Выявлено, что использование в составе рассола дополнительных рецептурных ингредиентов - комбинированной закваски на основе стартовых культур Lactobacillus brevis u Lactobacillus fermentum в количестве 5\% кмассе сырья и водного настоя плодов шиповника Даурского (Rosa Davurica) в количестве 0,5\% к массе сырья позволило сократить длительность таких проиессов производства корейки, как посол (выдержка в заливочном рассоле) на 24 ч и сушку на 24 ч.

Выявлено, что по содержанию белка $(13,2 \%)$ и жира $(27,8 \%)$ готовый продукт соответствует требованиям стандарта, предбявляемым к данному виду продукта. По соотношению ПНЖК:МНЖК:НЖК корейка «Пикантная» приближается к рекомендуемым нормам 10:60:30. Отмечено, что присутствие в настое аскорбиновой кислоты приводит $к$ снижению остаточного количества нитрита натрия почти в три раза в инновационном сырокопченом продукте из свинины, что повышает его пищевую безопасность. Доказано, что добавление стартовых культур L. brevis $u$ L. fermentum и настоя плодов шиповника Даурского в посолочный рассол оказывает положительное влияние на формирование высоких органолептических показателей корейки: вкуса, аромата, ивета и структурно-механических характеристик. Готовый продукт имеет монолитную, плотную консистенцию и насыщенный ивет. В работе также были проведены исследования по количественному учету жизнеспособных клеток L. brevis u L. fermentum в корейке "Пикантная», установлено, что количество жизнеспособных клеток в корейке на 25 сутки хранения $\left(1^{*} 10^{7} \mathrm{KOE} / 2\right)$, что соответствует требуемым нормам, предъявляемым $к$ пробиотическим продуктам.

\section{Введение.}

Современное промышленное производство пищевых продуктов, в том числе мясных, нацелено, с одной стороны, на экономическую эффективность, а с другой - на получение безопасных, питательных продуктов. В настоящее время снижается качество мясного сырья, особенно импортного, в связи с широким применением препаратов роста, поэтому необходимо предусмотреть способы корректировки свойств мяса с целью улучшения технологических свойств и потребительских показателей.

Для реализации поставленной цели в мясной отрасли широко применяют стартовые культуры. Вопросам целесообразности и эффективности использования бактериальных препаратов в производстве мясопродуктов посвящены научные исследования таких ученых, как В.В. Хорольский, И.С. Хамагаева, Н.К. Журавская и др. [1, 2, 3].
Keywords: meat product, nutritional value, starter cultures, dog-rose hips

\section{Abstract}

The article presents the results of the study on nutritional value of the uncooked smoked pork product with the complex brine. It was found that the use of the starter cultures on the basis of Lactobacillus brevis and Lactobacillus fermentum in an amount of 5\% by weight of the raw materials and the aqueous extract of dog-rose hips (Rosa Davurica) in an amount of $0.5 \%$ by weight of the raw materials, as recipe ingredients of the brine, allows reducing the duration of the drying process by 24 hours and the salting process also by 24 hours.

It was found that the product meets the requirements of the standard for this type of products by the content of protein (13.2\%) and fat $(27.8 \%)$. The uncooked smoked pork loin, which was made using starter cultures on the basis of Lactobacillus brevis and Lactobacillus fermentum and the aqueous extract of dog-rose hips, is close to the recommended ratio of PUFAs: MUFAs: SFAs (10:60:30). The authors also noted that the presence of ascorbic acid in the extract led to a significant decrease in the residual amount of sodium nitrite by almost three times in the innovative smoked pork product, which increased its food safety.

The results of the study showed that addition of the starter cultures L. brevis and L. fermentum and the extract of dog-rose hips (Rosa Davurica) to the brine during salting had a positive effect on the formation of the sensory characteristics of the pork loin: taste, aroma, color and its structural and mechanical properties. The product had the more monolithic, firm texture and rich color. The research on the quantitative detection of viable cells of L. brevis and L. fermentum in the uncooked smoked pork loin "Pikantnaya» was also done in this work. It was found that on the 25th day of storage, the total number of viable cells in the loin was $1^{*} 10^{7} \mathrm{CFU} / \mathrm{g}$, which corresponded to the requirements for the probiotic products.

\section{Introduction}

Modern industrial manufacture of food products, including meat products, is aimed, on one hand, at the economic efficiency and, on the other hand, at obtaining safe and nutritious food products. At present, the quality of meat raw materials, especially, imported meat raw materials decreases because of the wide use of growth promoters. Thus, today, it is very necessary to envisage methods for correcting the properties of meat to improve the technological properties and consumer characteristics.

To achieve this objective, the meat industry widely uses starter cultures. The research of such scientists as V.V. Khorolsky, I.S. Hamagaeva, N.K. Zhuravskaya and others is dedicated to the issues of expediency and effectiveness of using the bacterial preparations in the technology of meat products $[1,2,3]$. 
В настоящее время стартовые культуры являются неотъемлемой частью производства сырокопченых мясопродуктов, что подтверждается исследованиями зарубежных ученых $[4,5,6]$. Современные технологии с использованием стартовых культур направлены в основном на интенсификацию технологических процессов при обеспечении гарантированно высокого качества мясных изделий. Новым аспектом применения стартовых культур в технологии деликатесных изделий является использование лактобацилл, обладающих высокой функциональной активностью [7].

Пищевая ценность мясных изделий для потребителей, прежде всего, ассоциируется с их органолептическими показателями. Одним из важных показателей является цвет продукта. Эффективное усиление окраски мясопродуктов можно достигнуть за счет создания соответствующих окислительно-восстановительных условий. На практике такие условия достигаются при использовании аскорбиновой кислоты и ее солей, которые в большом количестве содержатся в растительном сырье $[8,9]$. Известно, что дикорастущие растения, такие как шиповник, боярышник, рябина и их настои, содержат в своем составе значительное количество аскорбиновой кислоты $[10,11]$. Поэтому актуальными становятся исследования по изысканию натуральных (природных) источников, содержащих аскорбиновую кислоту, для повышения безопасности продукта за счет предотвращения образования нитрозоаминов.

В связи с вышесказанным главная задача работы состояла в изучении влияния синергетического эффекта микроорганизмов и растительного сырья на биологическую и пищевую ценность сырокопченых мясных изделий из свинины.

Цель работы - изучение пищевой ценности цельномышечного сырокопченого мясного продукта из свинины.

\section{Материалы и методы}

В работе были приведены исследования по изучению качества инновационного продукта - корейки сырокопченой свиной, выработанной по технологии, предусматривающей комплексное использование закваски на основе Lactobacillus brevis и Lactobacillus fermentum и водного настоя плодов шиповника Даурского (Rosa Davurica).

Объектами исследований служили образцы корейки свиной сырокопченой (контроль) и корейки сырокопченой «Пикантная» (опыт). Контрольные образцы были выработаны по традиционной технологии, предусматривающей выделение свинины с неразрушенной структурой из спинной части отруба с ребрами по всей длине отруба шириной 14-15 см в шкуре, толщина подкожного шпика не более 4 см. Подготовка сырья перед посолом предусматривает удаление позвонков и заравнивание краев. Посол осуществляют шприцеванием рассолом

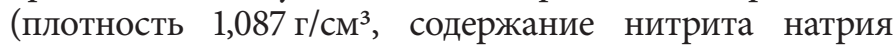
$0,05 \%$ и сахара $0,5 \%)$ в количестве $10 \%$ от массы сырья, затем натирают смесью соли (97\%) и сахара (3\%) в количестве 4\% и укладывают в чаны, выдерживают 1 сутки, прессуют и заливают рассолом (плотность 1,087 г/ $\mathrm{cm}^{3}$, содержание нитрита натрия $0,05 \%$, сахара - 0,5\%) в количестве 40-50\%. После этого сырье выдерживают в рассоле 5 суток, затем вне рассола - 1 сутки при температуре
Today, the starter cultures are an integral part of the production of smoked meat products $[4,5,6]$. Modern technologies with use of starter cultures are mainly aimed at process intensification upon producing meat products with the guaranteed high quality. The new aspect of a starter culture application in the technology of the deli meat products is the use of lactobacilli with high functional activity [7].

To consumers, a nutritional value of meat products is primarily associated with their sensory characteristics. The color of the product is one of the most important indicators. The effective enhancement of meat product color can be achieved through the establishment of appropriate redox conditions. In practice, such conditions are attained by using ascorbic acid and its salts, which are contained in large amounts in plant materials $[8,9]$. It is known that wild plants, such as dog-rose, hawthorn, mountain ash and their extracts contain a significant amount of ascorbic acid $[10,11]$. Therefore, the research, which is dedicated to finding the natural sources containing ascorbic acid for improvement of a product safety by preventing the formation of nitrosamines, is very topical.

In connection with the above-mentioned, the main task of this work was to study the influence of the synergistic effect of microorganisms and plant raw materials on the biological and nutritional value of smoked meat products from pork.

The objective of this work was the study of nutritional value of the smoked pork product.

\section{Materials and methods}

The paper presents the study on the quality of the innovative product - the uncooked smoked pork loin produced by the technology, which provides complex use of the starter cultures based on Lactobacillus brevis and Lactobacillus fermentum and the aqueous extract from dog-rose hips (Rosa Davurica).

The subjects of research were the samples of the uncooked smoked pork loin (control sample) and uncooked smoked loin «Pikantnaya» (test sample). The control samples were produced by the traditional technology, which included an excision of pork with an intact structure from the back part of a cut with ribs along the whole length of the cut (in skin) with the width of 14-15 cm; the thickness of the subcutaneous fat was not more than $4 \mathrm{~cm}$. Preparation of the raw material before salting involves the removal of vertebras and leveling the edges. Process of salting was carried out by injecting a brine (density of $1.087 \mathrm{~g} / \mathrm{cm}^{3}, 0.05 \%$ of sodium nitrite and $0,5 \%$ of sugar ) in an amount of $10 \%$ by weight of the raw material, then rubbing with a mixture of salt (97\%) and sugar $(3 \%)$ in an amount of $4 \%$ and placing into tubs for 24 hours; then the samples were pressed, and a brine (density of $1.087 \mathrm{~g} / \mathrm{cm}^{3}, 0.05 \%$ of sodium nitrite, $0.5 \%$ of sugar) was poured in an amount of $40-50 \%$. After that, the loin was held in brine for 5 days, then without brine for 1 day at $2-4{ }^{\circ} \mathrm{C}$. After salting, the loin was put into the water; a loop was made and the loin was left for water dripping and drying for 2-3 hours. The loin samples were smoked at $30-35^{\circ} \mathrm{C}$ for 24 hours, and then dried at 
$2-4{ }^{\circ} \mathrm{C}$. По окончании посола корейку вымачивают в воде, подпетливают, оставляют для стекания воды и подсушивания поверхности на 2-3 часа. Коптят корейку при 30-35 ${ }^{\circ} \mathrm{C}$ в течение 24 часов, затем сушат при $11 \pm 1^{\circ} \mathrm{C}$, относительной влажности воздуха $75 \pm 2 \%$ и скорости его движения $0,05-0,1 \mathrm{~m} / \mathrm{c}$ в течение 5 суток.

Опытные образцы корейки свиной сырокопченой «Пикантная» были изготовлены по усовершенствованной технологии, предусматривающей использование в составе рассола дополнительных рецептурных ингредиентов - комбинированной закваски на основе заквасочных культур Lactobacillus brevis и Lactobacillus fermentum в количестве 5\% к массе сырья и водного настоя плодов шиповника Даурского (Rosa Davurica) в количестве 0,5\% к массе сырья. Присутствие данных ингредиентов в рассоле позволило сократить длительность таких процессов производства корейки, как посол (выдержка в заливочном рассоле) на 24 ч и сушка на 24 ч.

Водный настой плодов шиповника был получен сме-

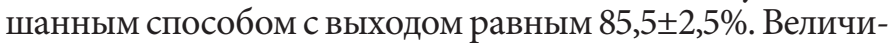
на $\mathrm{pH}$ настоя составила 3,48 , содержание сухих веществ - 1,23\%. В свежеприготовленном водном настое содержание витамина С составило 118,8 мг\% [12].

В ходе проведения эксперимента основные качественные показатели определяли стандартными методиками: содержание белка - методом Кьельдаля, в основе которого положена минерализация пробы по Кьельдалю, отгонки аммиака в растворе серной кислоты с последующим титрованием исследуемой пробы (ГОСТ 25011-81); содержание жира - методом Сокслета, основанным на многократной экстракции жира из подсушенной навески продукта органическим растворителем с последующим его удалением и взвешиванием обезжиренной навески (ГОСТ 23042-86); массовую долю хлорида натрия - аргентометрическим методом, основанным на титровании иона хлора ионом серебра в нейтральной среде в присутствии хромата калия (ГОСТ 9957-73); массовую долю остаточного количества нитрита натрия - фотометрическим методом, в основе которого лежит реакция с $\mathrm{N}$ - (1-нафтил) - этилендиамин дигидрохлоридом и сульфаниламидом в обезбелоченном фильтрате с дальнейшим фотометрированием интенсивности окраски пробы (ГОСТ 8558.1-78); органолептические показатели - по 9-ти балльной шкале, разработанной ВНИИМП [13]. Жирнокислотный состав исследовали методом хроматографии на газовом хроматографе Ajilent Packard HP6890 N с квадрупольным масс-спектрометром (HP MSD 5973) в качестве детектора; витаминный состав исследовали методом капельного электрофореза (Методика М 04-72-2011); количественный учет клеток молочнокислых бактерий проводили дифференциальным методом на модифицированной среде с Твином-80. Анализы выполнены в трехкратной повторности, результаты обработаны с использованием стандартных статистических методов.

\section{Результаты и их обсуждение.}

Анализ отечественной и зарубежной литературы показал, что основной особенностью технологии цельномышечных сырокопченых изделий является наличие совокупности разноплановых и взаимозависимых биохимических, физико-химических и
$11 \pm 1^{\circ} \mathrm{C}$, relative air humidity of $75 \pm 2 \%$, and air velocity of $0.05-0.1 \mathrm{~m} / \mathrm{s}$ for 5 days.

The test samples of the uncooked smoked pork loin «Pikantnaya» were manufactured by the advanced technology, which provides using the additional recipe ingredients in the composition of the brine: the starter culture on the basis of Lactobacillus brevis and Lactobacillus fermentum in an amount of $5 \%$ by weight of the raw materials and the aqueous extract of dogrose hips Daurskiy in an amount of $0.5 \%$ by weight of the raw materials. The presence of these ingredients in the brine has reduced the duration of such processes as salting (holding in brine) by 24 hours and drying by 24 hours.

The aqueous extract of dog-rose hips was obtained by a mixed method with a yield of $85.5 \pm 2.5 \%$. The $\mathrm{pH}$ of the extract was 3.48 , content of dry solids $-1.23 \%$. The content of vitamin $\mathrm{C}$ was $118.8 \mathrm{mg} \%$ in the fresh extract [12].

During the experiment, the main quality characteristics were determined by the standard methods: protein by the Kjeldahl method, which is based on the mineralization of a sample according to Kjeldahl, stripping of ammonia in a solution of sulfuric acid, followed by titration of the specimen (GOST 25011-81); fat by the Soxhlet method, based on the multiple fat extraction from a dried sample of a product by an organic solvent followed by its removal and weighing the defatted sample (GOST 23042-86); mass fraction of sodium chloride by the argentometric method, based on titration of the chlorine ion with the silver ion in a neutral medium in the presence of potassium chromate (GOST 9957-73); mass fraction of sodium nitrite residues by the photometric method, which is based on the reaction with $\mathrm{N}$-(1-Naphthyl) ethylenediamine dihydrochloride and sulfanilamide in a protein free filtrate with the following photometric testing of color intensity (GOST 8558.1-78); sensory characteristics with the 9-point scale developed by VNIIMP [13]. The fatty acid composition was examined by gas chromatography on the gas chromatograph Ajilent Packard HP6890 N with a quadrupole mass spectrometer (HP 5973 MSD) as a detector; quantitative detection of cells of lactic acid bacteria was carried out by the differential method using the modified medium with Tween-80. Analyses were carried out in triplicate, the mathematical processing of the results was performed using the standard statistical methods.

\section{Results and discussion}

Analysis of the Russian and foreign literature has shown that the main feature of the technology of whole-muscle uncooked smoked pork products is the presence of the aggregate of the diverse and interdependent chemical, physico-chemical and microbiological processes $[14,15,16]$. A product quality depends on the direction and degree of development of these processes.

Whole-muscle uncooked smoked meat products from pork belong to the high-calorie foods with specific taste and aroma, and they occupy a significant share 
микробиологических процессов $[14,15,16]$. От направленности и степени развития данных процессов зависит качество готовой продукции.

Цельномышечные сырокопченые мясные изделия из свинины относятся к высококалорийным продуктам со специфическим вкусом и ароматом и занимают не последнее место на российском рынке мясных продуктов. Деликатесная мясная продукции составляет 12-13\% в общей доли рынка мясных продуктов $[17,18]$.

Для оценки пищевой ценности и калорийности продукта был исследован его химический состав и физикохимические показатели (табл. 1). in the Russian market of meat products. Delicacy meat products account for $12-13 \%$ of the total market of meat products $[17,18]$.

The chemical composition and physico-chemical characteristics of the product were investigated to evaluate its nutritional value and caloric content (Table. 1).

The data of the research show that the finished product meets the requirements of the State Standard for this type of products by the content of protein and fat. According to GOST R 55796-2013, mass fraction of fat should be not more than $28 \%$, protein - no less than $13 \%$.

Table 1. The chemical composition and caloric content of the traditional and innovative products from pork

Таблица 1. Химический состав и калорийность традиционного и инновационного продуктов из свинины

\begin{tabular}{|c|c|c|}
\hline \multirow{2}{*}{ Characteristic| Показатель } & \multicolumn{2}{|c|}{ Quantity | Количество } \\
\hline & control | контроль & test | опыт \\
\hline \multicolumn{3}{|c|}{ Chemical composition | Химический состав } \\
\hline Protein, \% | Содержание белка, \% & $13,5 \pm 0,2$ & $13,2 \pm 0,2$ \\
\hline Fat, \% | Содержание жира, \% & $27,4 \pm 1,4$ & $27,8 \pm 1,2$ \\
\hline \begin{tabular}{|l|l|} 
Ash, \% & Массовая доля золы, \% \\
\end{tabular} & $4,3 \pm 0,04$ & $4,7 \pm 0,05$ \\
\hline Energy value, kkal | Энергетическая ценность, ккал & 315,6 & 314,4 \\
\hline \multicolumn{3}{|c|}{ The physicochemical characteristics | Физико-химические показатели } \\
\hline \begin{tabular}{|l|l|} 
Mass fraction of sodium chloride, \% & Массовая доля поваренной соли, \% \\
\end{tabular} & $3,8 \pm 0,1$ & $3,9 \pm 0,1$ \\
\hline $\begin{array}{l}\text { Mass fraction of the residual sodium nitrite, \% | } \\
\text { Массовая доля остаточного количества нитрита натрия, \% }\end{array}$ & $0,0047 \pm 0,0002$ & $0,00015 \pm 0,00005$ \\
\hline
\end{tabular}

Как показывают полученные данные по содержанию белка и жира, готовый продукт соответствует требованиям государственного стандарта, предъявляемым к данному виду продукта. Согласно ГОСТ Р 55796-2013 массовая доля жира должна быть не более $28 \%$, а белка не менее $13 \%$.

Результаты исследований физико-химических показателей свидетельствуют о значительном снижении доли остаточного нитрита натрия в корейке сырокопченой «Пикантная» относительно свиной корейки, изготовленной по традиционной технологии. Остаточное содержание нитрита натрия в контрольном образце было 4,7 мг на 100 г продукта, в то время как в опытном образце оно составило 0,15 мг на 100 г продукта. Вероятно, это объясняется наличием в составе водного настоя плодов шиповника аскорбиновой кислоты (118,8 мг/100 г), которая выступает в качестве восстановителя нитрита натрия, влияет на более полный распад нитрита натрия и переход его в нитрозопигменты.

На следующем этапе было исследовано влияние комбинированной закваски и водного настоя плодов шиповника на цветовые и вкусо-ароматические характеристики корейки сырокопченой «Пикантная». Проведена сравнительная дифференцированная органолептическая оценка контрольного и опытного образцов, результаты представлены в таблице 2.

Как видно из приведенных данных, сырокопченые изделия, приготовленные с применением закваски и настоя, характеризовались повышенной балльной оценкой органолептических показателей в отличие от корейки, изготовленной по традиционной рецептуре. Были отмечены более интенсивное окрашивание и выраженные аромат и вкус у изделий, изготовленных с применением стартовых культур и настоя.
The results of the investigation of the physico-chemical characteristics show a significant decrease in the mass fraction of sodium nitrite in the uncooked smoked loin «Pikantnaya» compared to the pork loin made by the traditional technology. The residual content of sodium nitrite in the control sample was $4.7 \mathrm{mg}$ per $100 \mathrm{~g}$ of the product while in the test sample it was $0.15 \mathrm{mg}$ per $100 \mathrm{~g}$ of product. This is probably due to the presence of ascorbic acid in the composition of the aqueous extract of dog-rose hips (118.8 mg / $100 \mathrm{~g}$ ), which acts as the reducing agent of sodium nitrite, and affects more complete decomposition of sodium nitrite and its transition into nitrozo pigments.

At the next stage, the authors have studied the effect of the complex starter cultures and the aqueous extract of dog-rose hips on the color and taste-and-aroma characteristics of the uncooked smoked loin "Pikantnaya»" The comparative differentiated sensory analysis of the control and test samples was done; the results are presented in Table 2 .

The data from table 2 show that the uncooked smoked product manufactured with the starter cultures and the extract has a higher score of the sensory characteristics compared to the pork loin, which was made according to the traditional recipes. More intense color and tasteand-aroma of the products manufactured with the use of the starter cultures and the extract were noted.

It was found that the use of the starter cultures based on Lactobacillus brevis and Lactobacillus fermentum and the aqueous extract of dog-rose hips promotes manufacturing a product with the more monolithic, dense texture, and color saturation.

The biological value of a product is one of the most important indicators that characterizes the quality of the 
Table 2. Sensory characteristics of the samples

Таблица 2. Органолептические показатели образцов

\begin{tabular}{|c|c|c|c|}
\hline \multirow[b]{2}{*}{ Sample | Образец } & \multicolumn{3}{|c|}{ Sensory characteristics, point | Органолептические показатели, балл } \\
\hline & $\begin{array}{c}\text { Color | Цвет, where } 1 \text { - } \\
\text { completely unacceptable, } \\
9 \text { points - very beautiful | } \\
\text { где } 1 \text { балл - совершенно } \\
\text { неприемлемый, } 9 \text { баллов } \\
\text { - очень красивый }\end{array}$ & $\begin{array}{c}\text { Taste | Вкус, } \\
\text { where } 1 \text { - completely } \\
\text { unacceptable, } 9 \text { points } \\
\text { - very tasty| где } 1 \\
\text { балл - совершенно } \\
\text { неприемлемый, } \\
9 \text { баллов - очень вкусный } \\
\end{array}$ & $\begin{array}{c}\text { Aroma | Запах, } \\
\text { where } 1 \text { - completely } \\
\text { unacceptable, } \\
9 \text { points - very pleasant | } \\
\text { где } 1 \text { балл - совершенно } \\
\text { неприемлемый, } 9 \text { баллов - } \\
\text { очень приятный } \\
\end{array}$ \\
\hline $\begin{array}{l}\text { Uncooked smoked loin (control sample) | } \\
\text { Корейка (контроль) }\end{array}$ & 7,0 & 8,0 & 8,0 \\
\hline $\begin{array}{l}\text { Uncooked smoked loin «Pikantnaya» (test } \\
\text { sample) | Корейка «Пикантная» (опыт) }\end{array}$ & 9,0 & 9,0 & 9,0 \\
\hline
\end{tabular}

Установлено, что применение закваски на основе Lactobacillus brevis и Lactobacillus fermentum и водного настоя плодов шиповника способствует получению продукта с более монолитной, плотной консистенцией и насыщенным цветом.

Важным компонентом, оказывающим существенное влияние на биологическую ценность готовой продукции, является жир. В составе мяса он представлен в основном триглицеридами.

Биологическая ценность липидов заключается в том, что они являются носителями больших запасов энергии и содержат не синтезируемые в необходимых количествах в организме человека высоконепредельные жирные кислоты. Триглицериды, содержащие большое количество радикалов ненасыщенных кислот, способствуют лучшему усвоению организмом белкового азота. Кроме того, жиры необходимы для всасывания в кишечнике жирорастворимых витаминов. Важная роль отводится им и при формировании аромата мяса.

Основным компонентом липидов являются жирные кислоты (ЖК). Насыщенные жирные кислоты (НЖК) используются организмом какэнергетический материал. Особое значение имеют мононенасыщенные (МНЖК) и полиненасыщенные жирные кислоты (ПНЖК), которые являются незаменимыми факторами питания. Линолевая, линоленовая и арахидоновая кислоты, принадлежащие к ПНЖК, по своим биологическим свойствам относятся к жизненно необходимым веществам. protein component and the fat component of a product.

An important component, which has a significant impact on the biological value of a product, is fat. It is contained in the composition of meat mostly as triglycerides.

The biological value of lipids resides in the fact that they are carriers of large stores of energy and contain the highly unsaturated fatty acids, which are not synthesized in the necessary quantities in a human body. Triglycerides, which contain large amounts of unsaturated fatty acid radicals, facilitate better assimilation of protein nitrogen by a body. In addition, fats are needed for intestinal absorption of fat soluble vitamins. They play an important role in the formation of meat flavor.

The major components of lipids are fatty acids (FA). Saturated fatty acids (SFAs) are used by a body as an energy material. Of particular importance are monounsaturated (MUFAs) and polyunsaturated fatty acids (PUFAs), which are essential nutritional factors. Linoleic, linolenic and arachidonic acids belonging to the PUFAs are the vital substances according their biological properties.

The authors have carried out an experimental determination of the fatty acid composition of the meat product, manufactured with the use of the probiotic microorganisms and the aqueous extract of dog-rose hips (Table 3).

Table 3. Fatty acid composition of the samples of the uncooked smoked pork loin

Таблица 3. Жирнокислотный состав образцов корейки сырокопченой

\begin{tabular}{|c|c|c|}
\hline \multirow{2}{*}{$\begin{array}{l}\text { Fattyacids | } \\
\text { Наименование жирной кислоты }\end{array}$} & \multicolumn{2}{|c|}{ The acid content,\% of the total content | Содержание кислот, \% к общему их содержанию } \\
\hline & control | контроль & test $\mid$ опыт \\
\hline $\begin{array}{l}\text { Saturated: | Насыщенные } \\
\text {-myristic (14:0)| } \mid \text { миристиновая } \\
\text {-palmitic (16:0)| пальмитиновая } \\
\text {-stearic(18:0)| стеариновая } \\
\end{array}$ & $\begin{array}{c}1,30 \\
22,38 \\
17,66 \\
\end{array}$ & $\begin{array}{c}0,67 \\
25,06 \\
11,05 \\
\end{array}$ \\
\hline Total | Итого & 41,34 & 36,78 \\
\hline $\begin{array}{l}\text { Monounsaturated: } \\
\text { - palmitoleic(16:1) } \\
\text {-oleic(18:1n9)| олеиноненасыщенные } \\
\text { - олылоя }\end{array}$ & $\begin{array}{c}3,97 \\
45,05\end{array}$ & $\begin{array}{c}2,27 \\
50,11\end{array}$ \\
\hline Total | Итого & 49,02 & 52,38 \\
\hline $\begin{array}{l}\text { Полиненасыщенные | Polyunsaturated: } \\
\text {-линолевая | linoleic(18:2) } \\
\text {-арахидоновая | arachidonic(20:4) }\end{array}$ & $\begin{array}{l}9,00 \\
0,64\end{array}$ & $\begin{array}{l}9,68 \\
1,16\end{array}$ \\
\hline Total | Итого & 9,64 & 10,84 \\
\hline Overall total | Всего & 100,0 & 100,00 \\
\hline
\end{tabular}


В работе было проведено экспериментальное определение жирнокислотного состава мясопродукта, изготовленного с применением пробиотических микроорганизмов и водного настоя плодов шиповника (табл. 3).

Согласно полученным результатам исследования в новом сырокопченом продукте преобладают из насыщенных жирных кислот - пальмитиновая кислота, а из мононенасыщенных жирных кислот - олеиновая кислота.

Современные представления о количественных и качественных потребностях человека в пищевых веществах отражены в концепции сбалансированного питания, учитывающей энергетические и биологические аспекты. В соответствии с ней соотношение между количеством полиненасыщенных и насыщенных жирных кислот должно составлять 0,3-0,35. Показатели жирнокислотной сбалансированности корейки, выработанной с использованием комбинированной закваски и настоя плодов шиповника, относительно эталона ФАО/ВОЗ представлены в таблице 4.

Анализ таблицы 4 показал, что соотношение между количеством полиненасыщенных и насыщенных жирных в корейке сырокопченой «Пикантная» составило 0,29 , что отвечает требованиям сбалансированного питания. Общепризнанным являются представления о том, что организм человека должен потреблять в составе липидов ПНЖК - 10\%, МНЖК - 60\%, НЖК - 30\%. Отношение ПНЖК:МНЖК:НЖК в корейке «Пикантная» отвечает принятым нормам, но при этом доля незаменимых полиненасыщенных ЖК составляла 10,81\% с преобладанием линолевой кислоты, которая участвует в биосинтезе арахидоновой кислоты. Последняя предшествует образованию веществ, участвующих в регулировании многих процессов жизнедеятельности тромбоцитов и других элементов, но особенно простагландинов, которым придают большое значение, как веществам высочайшей биологической активности.

Исследованиями доказано, что разработанная корейка «Пикантная» является продуктом, сбалансированным по пищевой ценности, и источником полиненасыщенных жирных кислот (линолевая и арахидоновая).

Витамины относятся к одним из жизненно необходимых веществ. Это органические соединения, большинство из которых не синтезируется в организме человека. Но при этом им отводится исключительная роль в обмене веществ, они входят в состав ферментов, влияют на иммунитет человека, делая его организм более устойчивым к болезням и стрессам. Поэтому ежедневно потребляемая пища должна обеспечивать поставку витаминов в организм человека в
According to the results of the research, in the new uncooked smoked product, palmitic acid predominated among the saturated fatty acids, oleinic acid among the monounsaturated fatty acids.

The present view of the quantitative and qualitative human needs for nutrients is reflected in the concept of balanced nutrition taking into account the energetic and biological aspects. In accordance with this concept, the ratio between the amount of polyunsaturated and saturated fatty acids should be $0.3-0.35$. The indicators of the fatty acid balance of the uncooked smoked loin, which was manufactured with use of the starter cultures and the extract of dog-rose hips are presented in Table 4 in comparison with the FAO / WHO standard.

The analysis of the data from Table 4 has shown that the ratio between the amount of the polyunsaturated and saturated fatty acids in the uncooked smoked loin «Pikantnaya» was 0.29 , which meets the requirements of balanced nutrition. It is widely accepted that a human body should consume $10 \%$ of PUFAs, $60 \%$ of MUFAs and $30 \%$ SFAs in the composition of lipids. The ratio of PUFAs: MUFAs: SFAs in the uncooked smoked loin "Pikantnaya» meets the accepted standards, while the proportion of the essential polyunsaturated FA is $10.81 \%$ with a predominance of linoleic acid, which is involved in the biosynthesis of arachidonic acid. The latter precedes the formation of the substances involved in the regulation of many vital processes of platelets and other elements, but especially prostaglandins - the substances of the highest biological activity.

The research has shown that the developed uncooked smoked loin "Pikantnaya» is a product balanced by nutritional value and a source of polyunsaturated fatty acids (linoleic and arachidonic).

Vitamins are among the essential substances. They are organic compounds, most of which are not synthesized in a human body. But at the same time, they are of primary importance in metabolism, are part of enzymes, affect the human immune system, make a human body more resistant to diseases and stresses. Therefore, daily consumption of food should ensure the supply of vitamins to the human body at least in amounts of the minimum daily requirement.

Based on the fact that the aqueous extract of dogrose hips was characterized by high content of ascorbic acid, the study on the quantification of vitamins in the product was carried out (Table 5).

It was found that the test samples of the loins were different from the control both by the quantitative

Table 4. The balance of fatty acid lipid of samples of pork's loin

Таблица 4. Показатели жирнокислотной сбалансированности липидов образцов корейки

\begin{tabular}{|c|c|c|c|c|c|c|}
\hline \multirow{3}{*}{$\begin{array}{l}\text { Sample | } \\
\text { Образец }\end{array}$} & \multirow{3}{*}{$\begin{array}{c}\text { The lipid } \\
\text { content, \% | } \\
\text { Содержание } \\
\text { липидов, \% }\end{array}$} & \multicolumn{5}{|c|}{$\begin{array}{l}\text { The acid content, \% of the total content | } \\
\text { Содержание кислот, \% к общему их содержанию }\end{array}$} \\
\hline & & \multirow{2}{*}{$\begin{array}{l}\text { ¿SFAs | } \\
\sum \text { НЖК }\end{array}$} & \multirow[b]{2}{*}{$\begin{array}{l}\text { ¿MUFAs | } \\
\sum \text { MHЖK }\end{array}$} & \multirow{2}{*}{$\begin{array}{l}\text { ¿PUFAs | } \\
\Sigma \text { ПНЖК }\end{array}$} & \multicolumn{2}{|c|}{\begin{tabular}{l|l} 
PUFAs & ПНЖЖК \\
\end{tabular}} \\
\hline & & & & & $\begin{array}{c}\text { linoleic | } \\
\text { линолевая }\end{array}$ & $\begin{array}{c}\text { arachidonic } \mid \\
\text { арахидоновая }\end{array}$ \\
\hline $\begin{array}{l}\text { Standard FAO/WHO } \\
\text { Эталон ФАО/ВО3 }\end{array}$ & - & 30,0 & 60,0 & 10,0 & 7,5 & 1,5 \\
\hline Control | Контроль & 27,4 & 41,34 & 49,02 & 9,64 & 9,00 & 0,64 \\
\hline Test | Опыт & 29,2 & 36,78 & 52,38 & 10,84 & 9,68 & 1,16 \\
\hline
\end{tabular}


количествах, по меньшей мере, минимальных относительно установленной суточной потребности.

Исходя из того, что водный настой плодов шиповника характеризовался достаточно высоким содержанием аскорбиновой кислоты, были проведены исследования по количественному определению витаминов в готовом продукте (табл. 5).

Table 5. The vitamin content in the uncooked smoked pork loin Таблица 5. Витаминный состав корейки сырокопченой

\begin{tabular}{|l|c|c|c|}
\hline \multirow{2}{*}{ Vitamins | Наименование витаминов } & \multirow{2}{*}{$\begin{array}{c}\text { The daily requirement, mg| } \\
\text { Суточная потребность, мг }\end{array}$} & The vitamins content, mg \% Содержаниевитаминов, мг \% \\
\cline { 3 - 4 } & & control | контроль & test | опыт \\
\hline Vitamin B1| Витамин В1 & 2,0 & $0,61 \pm 0,01$ & $0,86 \pm 0,01$ \\
\hline Vitamin B2 | Витамин B2 & 2,5 & $0,07 \pm 0,003$ & $0,14 \pm 0,002$ \\
\hline Vitamin PP | Витамин PP & 20,0 & $2,36 \pm 0,02$ & $2,41 \pm 0,02$ \\
\hline Vitamin C Витамин C & до 100,0 & - & $0,106 \pm 0,001$ \\
\hline
\end{tabular}

Установлено, что опытные образцы корейки отличались от контрольных как количественным, так и качественным витаминным составами. У опытных образцов была идентифицирована и количественно определена аскорбиновая кислота, ее содержание в готовом продукте составило 0,106 мг \%.

Уровень витаминов группы В в опыте был выше, чем в контроле, что объясняется введением в рецептуру, не только настоя, но и комбинированной закваски на основе Lactobacillus brevis и Lactobacillus fermentum. Известно, что молочнокислые микроорганизмы способны синтезировать витамины группы В, в частности тиамин и рибофлавин. Необходимо отметить, что содержание тиамина в опыте относительно суточной потребности человека составляет $43 \%$.

В работе также были проведены исследования по количественному учету жизнеспособных клеток L. brevis и L. fermentum в корейке «Пикантная» на 0, 25,30 сутки хранения готового продукта при температуре $0-4{ }^{\circ} \mathrm{C}$ относительной влажности $75 \pm 5 \%$. Результаты исследований показали, что в готовом продукте (0 сутки хранения) общее количество жизнеспособных клеток молочнокислых микроорганизмов составило $1,18^{\star} 10^{9} \mathrm{KOE} / г$, при дальнейшем хранении количество жизнеспособных клеток в корейке уменьшалось и к 25-тым суткам составило $1^{\star} 10^{7} \mathrm{KOE} / \Gamma$, а на конец срока годности (30 суток) - $1^{\star} 10^{6} \mathrm{KOE} /$. Известно, что рекомендуемое количество молочнокислых бактерий в пробиотических продуктах должно составлять не менее $1^{\star} 10^{7} \mathrm{KOE} / г$ [19]. Таким образом, в первые три недели после изготовления корейка «Пикантная» обладает пробиотическими свойствами.

\section{Выводы}

В результате проведенных экспериментальных исследований выявлено, что по содержанию белка $(13,2 \%)$ и жира $(27,8 \%)$ готовый продукт соответствует требованиям стандарта, предъявляемым к данному виду продукта. По соотношению ПНЖК:МНЖК:НЖК корейка «Пикантная» приближается к рекомендуемым нормам 10:60:30. Отмечено, что присутствие в настое аскорбиновой кислоты приводит к снижению остаточного количества нитрита натрия почти в три раза в инновационном сырокопченом продукте из свинины, and qualitative vitamin content. Ascorbic acid was identified and quantified in the test samples, its content in the product was $0.106 \mathrm{mg} \%$.

The content of vitamins B in the test samples was higher than in control, due to introducing into the recipe not only the extract, but also the combined starter culture based on Lactobacillus brevis and
Lactobacillus fermentum. It is known that the lactic acid bacteria can synthesize vitamins B, in particular, thiamine and riboflavin. It should be noted that the content of thiamine in the test sample is $43 \%$ of the daily requirement.

Also, the authors have done the research on the quantitative detection of viable cells of L. brevis and L.fermentum in the uncooked smoked loin «Pikantnaya» at $0,25,30$ days of storage of the finished product at a temperature of $0-4{ }^{\circ} \mathrm{C}$ and humidity of $75 \pm 5 \%$. The results showed that in the final product ( 0 days of storage) the total number of viable cells of the lactic acid microorganisms was $1,18^{*} 10^{9} \mathrm{CFU} / \mathrm{g}$; at the further storage, the number of viable cells in the uncooked smoked loin reduced and on the 25th day was $1^{\star} 10^{7} \mathrm{CFU} / \mathrm{g}$, while at the end of the shelf-life (30 days) it was $1^{\star} 10^{6} \mathrm{CFU} / \mathrm{g}$. It is known that the recommended amount of lactic acid bacteria in probiotic products should be no less than $1^{\star} 10^{7} \mathrm{CFU} / g$ [19]. Thus, the uncooked smoked loin «Pikantnaya» has probiotic properties during the first three weeks after manufacture.

\section{Conclusion}

The results of the experimental studies have shown that the finished product meets the requirements of the standard for this type of products by the content of protein $(13.2 \%)$ and fat (27.8\%). The uncooked smoked pork loin, which was made with the use of the starter culture on the basis of Lactobacillus brevis and Lactobacillus fermentum and the aqueous extract of dog-rose hips, is close to the recommended ratio of the PUFAs : MUFAs : SFAs (10:60:30). Authors also noted that the presence of ascorbic acid in the extract led to a significant decrease in the residual amount of sodium nitrite by almost three times in the innovative smoked pork product, which increased its food safety. Addition of the starter cultures $L$. brevis and L. fermentum and the extract of dog-rose hips (Rosa Davurica) to the brine during salting has a positive effect on the formation of the sensory characteristics of the pork loin: taste, aroma, color and its structur$\mathrm{al}$ and mechanical properties. The product has the more monolithic, firm texture and rich color. The research on the quantitative detection of viable cells of $L$. brevis and L. fermentum in the uncooked smoked loin from pork 
что повышает его пищевую безопасность. Добавление стартовых культур L. brevis и L.fermentum и настоя плодов шиповника Даурского в посолочный рассол оказывает положительное влияние на формирование высоких органолептических характеристик корейки: вкуса, аромата, окраски и структурно-механических характеристик. Готовый продукт имеет монолитную, плотную консистенцию и насыщенный цвет. В работе также были проведены исследования по количественному учету жизнеспособных клеток L. brevis и L. fermentum в корейке «Пикантная», установлено, что количество жизнеспособных клеток в корейке на 25 сутки хранения $\left(1^{\star} 107 \mathrm{KOE} / г\right)$, что соответствует требуемым нормам, предъявляемым к пробиотическим продуктам.

Таким образом, анализ полученных результатов экспериментальных исследований выявил преимущества совместного использования комбинированной закваски и водного настоя плодов шиповника в технологии цельномышечных сырокопченых мясопродуктов для повышения потребительских характеристик готового продукта.

\section{СВЕДЕНИЯ ОБ АВТОРАХ}

\section{Принадлежность к организации}

Забалуева Юлия Юрьевна - кандидат технических наук, доцент кафедры «Технологии мясных и консервированных продуктов» ФГБОУ ВПО «Восточно-Сибирский государственный университет технологий и управления», 670013, г. Улан-Удэ, ул. Ключевская 40в.

Тел.: 8(3012)417218

e-mail: aprilpolina@mail.ru

Баженова Баяна Анатольевна - доктор технических наук, профессор кафедры «Технологии мясных и консервированных продуктов» ФГБОУ ВПО «Восточно-Сибирский государственный университет технологий и управления», 670013, г. Улан-Удэ, ул. Ключевская 40в.

Тел.: 8(3012)417218

e-mail: bayanab@mail.ru

Назимова Ксения Сергеевна - кандидат технических наук Тел.: 8(3012)648434

e-mail: aprilpolina@mail.ru

\section{Критерии авторства}

Ответственность за работу и предоставленные сведения несут все авторы.

Все авторы в равной степени участвовали в этой работе.

Забалуева Ю.Ю. разработала способ получения водного настоя плодов шиповника, изучила его качественные характеристики и провела анализ данных по качественным показателям кореек из свинины сырокопченых (опыт и контроль);

Баженова Б.А. выявила влияние настоя из плодов шиповника и комбинированной закваски на витаминный и жирнокислотный составы корейки свиной сырокопченой.;

Назимова К.С. занималась описательной частью, а также провела исследования по динамике количественного учета жизнеспособных клеток L. brevis и L. fermentum.

Авторы в равных долях имеют отношение к написанию рукописи и одинаково несут ответственность за плагиат

Баженова Б.А. корректировала рукопись до подачи в редакцию

$$
\text { Конфликт интересов }
$$

Авторы заявляют об отсутствии конфликта интересов

Поступила 25.12.2015
«Pikantnaya» was also carried out. It was found that on the 25 th day of storage, the total number of viable cells of the lactic acid microorganisms in the product was $1^{\star} 10^{7} \mathrm{CFU} / \mathrm{g}$, which corresponded to the requirements for probiotic products.

Thus, the analysis of the results of the experimental studies has shown the benefits of the combined use of the starter culture and the aqueous extract of dog-rose hips in the technology of whole-muscle uncooked smoked meat products for increasing consumer characteristics of the product.

\section{AUTOR INFORMATION Affiliation}

Zabalueva Yuliya Yurievna - Candidate of Engineering Sciences, Associate Professor at the Department of Technology of meat and can products, East-Siberian State University of technology and management, 670013, Ulan-Ude, st. Kluchevskaya, 40v

Ph.: 8(3012)417218

e-mail: aprilpolina@mail.ru

Bazhenova Bayana Anatolievna - Doctor of Science, Associate Professor at the Department of Technology of meat and can products, East-Siberian State University of technology and management, 670013, Ulan-Ude, st. Kluchevskaya, 40v

Ph.: 8(3012) 417218

e-mail: bayanab@mail.ru

Nazimova Kseniya Sergeevna - Candidate of Engineering Sciences Ph.: 8(3012)648434

e-mail: aprilpolina@mail.ru

\section{Contribution}

All authors have responsibility for the information in manuscript. All authors involved in this work in equal parts.

Zabalueva Yu.Yu. has developed a method for producing an aqueous extract from dog-rose hips, she studied its qualitative characteristics and analyzed the data on quality indicators of uncooked smoked loin from pork (test and control);

Bazhenova B.A. revealed the impact of the extract from dog-rose hips and complex leaven on the contents of vitamin and fatty acids in smoked pork loin;

Nazimova K.S. took part in the descriptive part, and she conducted research of the dynamics of the quantitative determination of viable cells L. brevis and L. fermentum.

Authors equally relevant to the writing of the manuscript, and equally responsible for plagiarism

Bazhenova B.A. adjusted the manuscript prior to submission to the Editor

\section{Conflict of interest}

The authors declare there is no conflict of interest

Received 25.12.2015 


\section{БЛБЛИОГРАФИЧЕСКЛЙ СПИСОК}

1. Хорольский В.В., Митасева М.Ф., Машенцева Н.Г., Бучинская А.Г. Молочные микроорганизмы в технологии мясных продуктов // Мясная индустрия, 2006. №5. С.34

2. Хамагаева И.С., Ханхамаева И.А., Хамаганова И.В., Никифорова А.П. Применение пропионовокислых бактерий Аия производства продуктов из говядины // Вестник ВСГУТУ, 2012. № 3 (38). C.97-101.

3. Журавская Н.К., Фофанова Т.С., Михайлова М.М. Исследование перспектив применения бактерий стартовых культур при производстве охлажденных рубленых полуфабрикатов: тез. доки. 4-й всесоюзной науч. -техн. конф. - М., 1990.

4. Casquete R., Benito M.J., Martín A., Ruiz-Moyano S., Hernán$\operatorname{dez}$ A., Córdoba M.G. Effect of autochthonous starter cultures in the production of "salchichón", a traditional Iberian dry-fermented sausage, with different ripening processes // LWT - Food Science and Technology, 2011. V. 44, Issue 7, P. 1562-1571.

5. Työppönen S., Petäjä E., Mattila-Sandholm T. Bioprotectives and probiotics for dry sausages // International Journal of Food Microbiology, 2003. V. 83, Issue 3, P. 233-244.

6. Ravyts F., De Vuyst L., Leroy F. Bacterial diversity and functionalities in food fermentations // Engineering in Life Sciences. Special Issue: Biotechnology of fermented food systems, 2012. V. 12, Issue 4, P. 356-367.

7. Назимова К.С. Забалуева Ю.Ю., Аанилов М.Б. Пробиотические микроорганизмы и настои из Аикорастущих растений дия мясных продуктов // Мясная индустрия, 2008. № 8. С. 38-39.

8. Баженова Б.А., Амагзаева Г.Н., Аанилов М.Б. Формирование окраски вареных колбас с биологически активной добавкой // Мясная индустрия, 2011. № 12. С.46-50. 9. Баженова Б.А., Колесникова И.С. Технология производства обогащенного мясного продукта // Мясная индустрия, 2012. № 2. С. 48-50.

10.Забалуева Ю.Ю., Баженова Б.А. Влияние настоев дикорастущих растений Забайкалья на цветообразование мясных продуктов // Мясная индустрия, 2006. № 7. С. 21-22. 11.УАачина Б.Г., Горбунова Ю.Н. Рябина: пищевая ценность, сорта, новое в размножении, основы агротехники // Картофель и овощи, 1991. № 1. С. 24-26.

12. Забалуева Ю.Ю., Баженова Б.А. Получение биологически активной пищевой Аобавки Аия мясных продуктов // Известия вузов. Прикладная химия и биотехнология, 2015. № 4. C. 75-82.

13. Забалуева Ю.Ю. Методы исследования мяса и мясных продуктов: учеб.-практ. пособие / Ю.Ю. Забалуева. - Улан-УАэ: ИзА-во ВСГУТУ, 2011. - 92 с.

14. Рогов И.А., Жаринов А.И., Текутьева А.А., Шепель Т.А. Биотехнология мяса и мясопродуктов: курс лекций. - М.: АеАи Принт, 2009. - С. 226-253.

15. Ockerman H.W., Basu L. Fermented Meat Products: Production and Consumption [электронный ресурс]. - Режим доступа: https://kb.osu.edu/dspace/bitstream/handle/1811/45275/ fermented?sequence=1 (Аата обращения: 15.01.2016).

16. Fermented Sausages [электронный ресурс]. // Wedliny Domowe. - Режим доступа: http://www.meatsandsausages. com/sausage-types/fermented-sausage. (Аата обращения: 05.03.2016)

17. Колезнева Е. Обзор российского рынка колбасных изделий и мясных деликатесов // Russian Food\&Drinks Market Magazine, 2010. № 5.

18. Ковалева И.В., Сурай Н.М. Маркетинговые исследования локального рынка мясных деликатесов и мясной продукции // Техника и технология пищевых производств, 2015. № 4 (39). С. 151-155.

19. Журавлева С.В., Прокопец Ж.Г. Биологическая и пищевая ценность пробиотических пастообразных продуктов из сырья морского генеза // Техника и технология пищевых производств, 2012. № 4. С. 18-23.

\section{REFERENCES}

1. Khorolsky V.V., Mitaseva L.F., Mashentseva N.G., Buchynska A.G. Dairy microorganisms in meat products technology // Meat Industry, 2006. № 5. P. 34

2. Hamagaeva I.S., Hanhalaeva I.A., Khamaganova I.V., Nikiforova A.P. Use of propionic acid bacteria for the production of beef // Vestnik of ESSUTM, 2012. № 3 (38).P. 97-101.

3. Zhuravskaya N.K., Fofanova T.S., Mikhailova M.M. Research of prospects of using bacterial starter cultures in the production of chilled semi-finished products: mes. rep. 4th All-Union Scientific.TechnoExpert.Conf. - M., 1990.

4. Casquete R., Benito M.J., Martín A., Ruiz-Moyano S., Hernández A., CórdobaM.G. Effect of autochthonous starter cultures in the production of "salchichón", a traditional Iberian dry-fermented sausage, with different ripening processes // LWT - Food Science and Technology, 2011. V. 44, Issue 7, P. 1562-1571.

5. Työppönen S., Petäjä E., Mattila-Sandholm T. Bioprotectives and probiotics for dry sausages //International Journal of Food Microbiology, 2003. V. 83, Issue 3, P. 233-244.

6. Ravyts F., De Vuyst L., Leroy F. Bacterial diversity and functionalities in food fermentations // Engineering in Life Sciences. Special Issue: Biotechnology of fermented food systems, 2012 V. 12, Issue 4, P. 356-367.

7. Nazimova K.S., Zabalueva Yu.Yu., Danilov M.B. Probiotic microorganisms and extracts from wild plants for meat products // Meat Industry, 2008. № 8. S. 38-39.

8. Bazhenova B.A., Amagzaeva G.N., Danilov M.B. Formation of the color of cooked sausages with biological active supplement // Meat Industry, 2011. № 12. P. 46-50.

9. Bazhenova B.A., Kolesnikova I.S. Technology of production of enriched meat product// Meat Industry, 2012. № 2. P. 48-50.

10. Zabalueva Yu.Yu., Bazhenova B.A. Effect of extracts of wild plants of Zabaikaliya on color formation of meat products // Meat Industry, 2006. № 7. P. 21-22.

11. Udachina B.G., Gorbunova Yu.N. Rowan: food value, varieties, new in reproduction, the basics of farming // Potatoes and vegetables, 1991. № 1. P. 24-26.

12. Zabalueva Yu.Yu., Bazhenova B.A. Preparation of biologically active food additive for meat products // Proceedings of the universities. Applied Chemistry and Biotechnology, 2015. № 4. P. 75-82.

13.Zabalueva Yu.Yu. Methods of research of meat and meat products: benefit. - Ulan-Ude: Univ ESSUTM, 2011. - 92 p.

14. Rogov I.A., Zharinov A.I., Tekuteva L.A., Shepel T.A. Biotechnology of meat and meat products: a series of lectures. - M .: Print DeLee, 2009. P. 226 - 253.

15. Ockerman H.W., Basu L. Fermented Meat Products: Production and Consumption [electronic resource]. - Access mode:https://kb.osu.edu/dspace/bitstream/handle $/ 1811 / 45275 /$ fermented?sequence $=1$ (Date of access: 15.01.2016).

16. Fermented Sausages [electronic resource]. // WedlinyDomowe. - Access mode: http://www.meatsandsausages.com/ sausage-types/fermented-sausage. (Date of access: 05.03.2016) 17. Kolezneva E. Review of the Russian market of sausage products and meat delicacies // Russian Food \& Drinks Market Magazine, 2010. № 5 .

18. Kovaleva I.V., Surai N.M. Marketing research of the local market deli meats and meat products // Engineering and technology of food production, 2015. № 4 (39). P. 151-155.

19. Zhuravleva S.V., Prokopets J.G. The biological and food value of probiotic paste products from raw materials of marine origin // Engineering and technology of food production, 2012. № 4. P. 18-23. 